\title{
Aparecida: da imagem à mensagem
}

Recebido: 28/05/2017. Aprovado: 31/07/2017.

\author{
Luiz Harding Chang* \\ Wellington Cristiano da Silva**
}

Resumo: A devoção a Nossa Senhora da Conceição Aparecida nasce da experiência de fé do povo brasileiro. Encontrada nas águas do Rio Paraíba em 1717, a imagem de Aparecida contém uma mensagem profética vinda do céu. Transcendendo o aspecto puramente iconográfico, somos capazes de interpretar, à luz da revelação cristã, o significado teológico presente na pequena imagem da Virgem Negra. Aparecida, além de ser um lugar teológico, é, igualmente, um lugar antropológico. O povo lê, em Aparecida, a sua própria vida. Sinal de esperança para o povo peregrino, a imagem de Nossa Senhora Aparecida, em sua trajetória de trezentos anos, tem muito ainda a nos dizer e a nos ensinar.

Palavras-chave: Aparecida. Piedade Popular. Teologia da Imagem.

Abstract: The devotion to Our Lady of the Conception Apparition borns of the faith experience of Brazilian people. The image of Aparecida was found in the waters of the Paraiba river in 1717 and it has a prophetic message from heaven. Transcending the purely iconographic aspect, there is a theological meaning in the small image of the Black Virgin that we are able to interpret in the light of Christian revelation. Besides being a locus theologicus, Aparecida is also an anthropological locus. The people read in Aparecida their own life. A sign of hope for the pilgrims, the image of Our Lady Aparecida, in its three hundred year trajectory, has much more to tell us and to teach us.

Keywords: Aparecida, Popular pity, Theology of the image.

* Mestre em Sacred License Theology (STL-2007), Boston College, USA. Graduado em Arquitetura e Urbanismo (1991), Universidade Federal de Santa Catarina, Florianópolis, SC. Graduado em Master of Divinity (MDiv - 2005), Boston College, USA. Graduado em Filosofia (2000), Faculdade Jesuíta de Filosofia e Teologia, Belo Horizonte, MG. E-mail: Ichangsj@gmail.com

** Especializando em Mariologia, Faculdade Dehoniana, Taubaté, SP. Bacharelado em Teologia (2014), PUC-RS. Bacharelado eclesiástico em Teologia (2011), ITESC. Bacharel em Filosofia (2008), Faculdade São Luiz, Brusque, SC.

E-mail:welli_83@yahoo.com.br 
Em comemoração aos trezentos anos do encontro da imagem de Nossa Senhora da Conceição Aparecida, a Conferência Nacional dos Bispos do Brasil proclamou o Ano Nacional Mariano, que teve início no dia doze de outubro de 2016 e se encerrará no dia 11 de outubro de 2017. A visita da imagem jubilar de Nossa Senhora Aparecida às dioceses do Brasil, as obras de acabamento do Santuário Nacional, o Rota 300, os monumentos dedicados a Nossa Senhora Aparecida inaugurados nos jardins do Vaticano, em Aparecida e na sede da CNBB, são algumas das atividades que marcam esta celebração de ação de graças.

Este Ano Mariano ${ }^{1}$ tem o objetivo de intensificar a devoção à Virgem Maria, sob o título de Aparecida, e, por meio dessa devoção, aprender com ela o seguimento de Jesus. Pois, como ressalta a Exortação Apostólica Marialis Cultus do Papa Paulo VI, "na Virgem Maria, de fato, tudo é relativo a Cristo e dependente dele" (MC, 25).

\section{Piedade popular enquanto lugar teológico}

A devoção a Nossa Senhora da Conceição Aparecida nasce do povo. $\mathrm{O}$ culto à Virgem de Aparecida se deu, inicialmente, num ambiente doméstico, semelhante às origens das primeiras comunidades cristãs. A pequenina imagem encontrada nas águas barrentas do Rio Paraíba, na segunda quinzena de outubro de 1717 , foi conduzida, primeiramente, à casa de Filipe Pedroso, um dos três pescadores que acharam a imagem. Em 1932, Filipe entregou-a a seu filho Atanásio. Este construiu um pequeno oratório onde a vizinhança reunia-se para a oração do terço. Somente em 1745, devido à inúmera ocorrência de milagres e consequentes peregrinações, foi construída oficialmente a primeira capela que abrigou a imagem. Bastaram algumas poucas gerações para que a devoção, que nasceu em um vilarejo de pescadores, se tornasse uma devoção nacional. Este grande fenômeno popular levou o Papa Pio XI a proclamar, em 16 de julho de 1930, Nossa Senhora Aparecida padroeira do Brasil.

Tratando-se de uma devoção popular legítima, Aparecida tornase, para nós, um lugar teológico, um ambiente para a reflexão teológica, não menos importante que a devoção. Neste sentido, declara o Documento de Aparecida: "Não podemos desvalorizar a espiritualidade

Vale lembrar ainda que, neste mesmo ano, comemoramos o centenário das aparições em Fátima e os trinta anos da publicação da encíclica Redemptoris Mater de João Paulo II. 
popular ou considerá-la como modo secundário da vida cristã, porque seria esquecer o primado da ação do Espírito e a iniciativa gratuita do amor de Deus" (DAp, 263). Chama-nos a atenção o fato de que o Documento de Aparecida qualifica a devoção popular como uma verdadeira espiritualidade ou mística popular (DAp, 262-263), "ou seja, uma espiritualidade cristã que, sendo um encontro pessoal com o Senhor, integra muito o corpóreo, o sensível, o simbólico e as necessidades mais concretas das pessoas" (DAp, 263). A devoção popular é, de fato, uma espiritualidade encarnada na vida e na cultura dos humildes de coração. É uma forma profunda de viver a fé, de estar unido à Igreja e de ser discípulo missionário (DAp, 264).

No pensar teológico, não podemos desqualificar ou menosprezar as manifestações religiosas que nascem da fé do povo simples. Muitas comunidades, sem assistência de padres e religiosos, foram nutridas, durante longos períodos, pela espiritualidade popular, como memória viva do evangelho. Muitos fiéis encontram em suas devoções particulares alimento consistente para sua vida espiritual. Na Exortação Apostólica Evangelii Gaudium, o Papa Francisco afirma que "as expressões da piedade popular têm muito que nos ensinar e, para quem as sabe ler, são um lugar teológico a que devemos prestar atenção particularmente na hora de pensar a nova evangelização" (EG, 126). O Papa Francisco não apenas reconhece a relevância pastoral e espiritual da piedade popular, mas declara sua relevância teológica, enquanto lugar hermenêutico e fonte para teologia.

Contudo, a devoção popular ${ }^{2}$, de modo especial a devoção mariana, precisa passar também por um crivo de discernimento pastoral e teológico. "Quando afirmamos que é necessário evangelizá-la ou purificá-la, não queremos dizer que esteja privada de riqueza evangélica. Simplesmente desejamos que todos os membros do povo fiel, reconhecendo o testemunho de Maria e dos santos, procurem imitá-los cada dia

2 As devoções populares são expressões do culto cristão, distintos da Liturgia, mas que a ela conduzem. As devoções não possuem caráter de obrigatoriedade. São práticas religiosas propostas livremente aos fiéis. "A Liturgia, por sua vez, é a expressão cultual oficial da Igreja. Caracteriza a identidade da Igreja como comunidade orante e tem maior normatização" (MURAD, Afonso. Maria, toda de Deus e tão humana: Compêndio de mariologia. São Paulo: Paulinas; Aparecida: Santuário, 2012. p. 203). Um grande perigo que podemos correr é o de transformar as devoções em algo rígido, distante da Palavra de Deus e fora da centralidade de Jesus Cristo. Por conseguinte, é preciso estar atento a certas manifestações devocionais, a fim de perceber se caminham ou não conforme as orientações da Igreja (cf. SC, 13). 
mais" (DAp, 262). Esta experiência despertará no fiel o desejo de estar mais próximo da Palavra de Deus, da Liturgia, da Comunidade de fé e do serviço do amor solidário (cf. DAp, 262). Vale ainda retomar o que ensinou o Concílio Vaticano II: "Importa, porém, ordenar essas práticas tendo em conta os tempos litúrgicos, de modo que se harmonizem com a sagrada Liturgia, de certo modo derivem dela, e a ela, que por sua natureza é muito superior, conduzam o povo" (SC, 13). Há de se verificar sempre se as manifestações populares estão conduzindo o fiel à vivência dos sacramentos, à participação na Liturgia, à inserção na comunidade e à caridade evangélica, favorecendo a adesão a Jesus Cristo e ao projeto do Reino.

É importante também distinguir devoção popular de devoção midiática. Hoje muito do que chamamos de piedade popular não passa de uma devoção que "caiu de paraquedas" no seio de nossas comunidades. O Documento de Aparecida afirmara que a piedade popular penetra a existência de cada fiel, não se confundindo com uma espiritualidade de massas (DAp, 261). Fruto da propaganda religiosa, a devoção midiática acaba suprimindo os autênticos exercícios piedosos do povo cristão.

Atualmente, com o advento da sociedade midiática e da cultura urbana, sobraram poucas manifestações marianas autenticamente populares, que nascem e se desenvolvem espontaneamente. Predomina a devoção midiática, que já não é popular, nem em sua origem nem no protagonismo. Suas práticas devocionais são geradas, apoiadas e difundidas por pessoas e grupos organizados, nos quais se incluem padres, leigos, institutos religiosos, novas comunidades e movimentos eclesiais bem determinados ${ }^{3}$.

A devoção midiática, por vezes, mata ou tenta abolir a genuína devoção popular. O crescente devocionismo não tem raízes na vida e na fé do povo. São instrumentos de um catolicismo de público, da cultura de massa impregnada na Igreja. São imposições subjetivas provenientes de certos setores da Igreja, apoiados por um considerável número de líderes católicos. O exercício de tais devoções é justificado pelo pretexto de atrair fiéis para Igreja.

As devoções, quando instrumentalizadas, perdem sua legitimidade em nome de uma evangelização baseada na superficialidade do mero

3 MURAD, Afonso. A devoção marial no Brasil contemporâneo: olhar panorâmico. Vida Pastoral, São Paulo, ano 56, n. 304, p. 3-14, jul/ago. 2015. p. 14. 
espetáculo. A autêntica devoção a Maria e aos santos "não reside no fato de ser atrativa e reunir multidões nem em constituir uma 'isca' para outras práticas devocionais e litúrgicas"4. O critério para se verificar a autenticidade das devoções será único: é legítima e saudável aquela devoção vivida no horizonte da centralidade de Jesus e do Reino de Deus ${ }^{5}$.

\section{A teologia da imagem}

A iconografia de Aparecida - A teologia da imagem foi o tema contemplado pelo IX Congresso Mariológico, realizado em 2015, em Aparecida. Em síntese, o Congresso buscou aprofundar a teologia da imagem de Maria, numa perspectiva bíblica, teológica, histórica e pastoral, partindo da imagem de Nossa Senhora Aparecida e de sua mensagem para a caminhada de fé da Igreja no Brasil. ${ }^{6}$

Neste ano jubilar, nós, brasileiros, somos convidados a contemplar e reinterpretar, à luz da fé, a imagem de Nossa Senhora Aparecida, encontrada nas águas do Rio Paraíba do Sul e a retomar o itinerário histórico-religioso que envolve este ícone da fé cristã no Brasil.

Desde os primeiros séculos, os cristãos buscaram expressar, através da arte, temas de fé. Os ícones tinham uma finalidade catequética e litúrgica. Na contemplação iconográfica, o fiel lia a história da salvação. As imagens do Cristo e de sua mãe tinham um significado objetivo, sempre associadas ao mistério salvífico. A Teologia e a Liturgia estavam refletidas e impressas na arte.

A iconografia é a história da salvação escrita em imagem artística. Nesse sentido, o fiel é impulsionado a extrair da imagem o seu significado teológico. Ultrapassando as formas do imediatamente dado, ele chega à experiência do mistério. Só quem é capaz de dar o salto da imagem (iconografia) para o significado contido nela (iconologia) ${ }^{7}$, supera o risco da idolatria; não se deixa levar apenas pela beleza das formas, mas adentra na profundidade do mistério representado.

\footnotetext{
Murad, 2015, p. 14.

5 Ibid., p. 14.

6 Cf. GUIMARÃES, Valdivino (Org.). Iconografia de Aparecida: Teologia da Imagem. São Paulo: Paulus, 2026. p. 7.

7 Trata-se do método de leitura artística introduzido por Erwin Panofsky (1892-1968), que consiste, basicamente, na descrição pré-iconográfica, na análise iconográfica e na interpretação iconológica (estudo do significado do conteúdo da obra de arte).
} 
A Igreja ensina em sua doutrina que "a iconografia cristã transcreve pela imagem a mensagem evangélica que a Sagrada Escritura transmite pela palavra. Imagem e palavra iluminam-se mutuamente!' (CIC, 1160), tendo um recíproco significado. Todas as imagens da Virgem e dos santos são relativas a Cristo. Elas significam o Cristo que é glorificado em suas testemunhas. Através dos ícones, "revela-se à nossa fé o homem criado à imagem de Deus e transfigurado à sua semelhança" (CIC, 1161).

A imagem religiosa "exerce a ação de duas forças na pessoa que a contempla: a mensagem que deseja comunicar tal como foi elaborada (diria o escultor: 'Vou fazer uma imagem de Nossa Senhora'), e a reação subjetiva que alguém sente diante dela. A experiência humana resulta de uma tensão entre realidades exteriores e sensíveis e impressões interiores subjetivas"8. Ao contemplar uma imagem religiosa, o fiel é levado a ultrapassar o sensorial, o material, e adentrar no mistério. "Isso significa que o poder da imagem não vem do objeto, do signo, da forma ou da materialidade, mas do significante que lhe dá sustento" ". Ao transcender o signo, ou seja, a forma dada à matéria, o crente se distancia da idolatria e se transforma num mistagogo. Todavia, a imagem, embora represente o mistério, também se distancia dele ${ }^{10}$. A imagem não contém o mistério, mas apenas o representa, e sua representação é limitada.

$\mathrm{Na}$ arte sacra das origens, o caráter cristológico das imagens era bastante nítido. A figura da Virgem estava sempre associada à de seu filho. Os Padres da Igreja contemplavam em Maria o mistério do Verbo encarnado. Com o passar dos séculos, a imagem de Maria foi ganhando certa autonomia, distanciando-se, por vezes, de sua característica cristológica que lhe é intrínseca. A serva do Senhor foi assumindo traços de Rainha, com suas coroas, mantos e palácios. Hoje, contudo, o grande desafio é o de encontrar, por debaixo das camadas das tintas devocionais do período medieval e moderno, o rosto humano de Maria de Nazaré.

$\mathrm{Na}$ imagem de Maria achada nas águas do Paraíba por três pescadores transparece, em primeiro lugar, o sentido da santidade da mãe do Senhor. Eis que das águas turvas de um rio emerge a imagem da Imaculada Conceição. Nela está representado o mistério de Maria preservada, pela graça, da corrupção de toda mancha do pecado origi-

8 CAVACA, Osmar. De quem é esta imagem? In: Iconografia de Aparecida: Teologia da Imagem. São Paulo: Paulus, 2016. p. 13.

9 Ibid., p. 13-14.

10 Ibid., $\mathrm{p} 14$. 
nal, desde o início de sua existência, em vista dos méritos de Cristo. A imagem da Imaculada Conceição de Maria, intimamente ligada à figura simbólica da mulher do capítulo doze do Apocalipse de São João, faz eco à vitória de Cristo sobre a antiga serpente. A esta vitória de Cristo sobre o pecado e o mal está vinculada a sua mãe. Maria é imagem da Igreja glorificada e plenificada em Cristo Jesus. O que causa uma certa estranheza é a coloração da imagem. A Imaculada encontrada no Paraíba é negra. A cor que a imagem traz consigo sinaliza um sentido antropológico e teológico novo, que precisa ser interpretado como um verdadeiro sinal profético. Na imagem negra de Aparecida, Deus tem algo a nos transmitir.

\section{Aparecida: sinal profético}

Aparecida foi um título carinhoso que o povo simples deu à imagem de Nossa Senhora da Conceição achada nas águas do Rio Paraíba. Em Aparecida, contudo, não nos deparamos com uma aparição da Virgem, semelhante às aparições em Guadalupe, Fátima, Lourdes ou Salete. Não há videntes e nem mensagens divinas confiadas a videntes. Em Aparecida, temos apenas uma imagem, uma pequeninha imagem quebrada, escurecida pelo tempo em que ficou nas profundezas do Paraíba. Se há uma mensagem em Aparecida, ela está contida na própria imagem e em toda a sua trajetória, desde o momento em que foi lançada nas águas até os dias de hoje.

Além de transmitir a verdade de fé acerca da Imaculada Conceição - que, aliás, no século XVIII não era ainda definida dogmaticamente como tal -, a imagem de Aparecida remete a novos significados. A imagem de Aparecida, em tempos marcados pela exploração humana e pela exploração da natureza, surge como um sinal profético, um sinal que precisa ser interpretado à luz dos sinais dos tempos, pelos quais Deus continua a nos dizer algo. Na imagem de Aparecida, há uma mensagem vinda do céu. O Papa Francisco, no seu discurso dirigido ao episcopado brasileiro por ocasião da JMJ 2013, apresentou Aparecida como chave de leitura para a missão da Igreja, e afirmou: "Há algo de perene para aprender sobre Deus e sobre a Igreja, em Aparecida; um ensinamento, que nem a Igreja no Brasil nem o próprio Brasil devem esquecer"11.

11 FRANCISCO. Aparecida: Chave de leitura para a missão da Igreja. In: Os Papas e o Santuário de Aparecida. Coleção Theotókos. V. 15. Brasília: CNBB, 2016. p. 48. 


\subsection{Antes da pesca}

Desconhecemos o autor da pequena imagem de Nossa Senhora Aparecida. Ela não foi assinada, nem datada. Alguns peritos confirmam que a imagem é do século XVII, por possuir traços da arte seiscentista. Chegam até a afirmar se tratar de uma obra do monge beneditino Frei Agostinho da Piedade ou de seu confrade, Frei Agostinho de Jesus, ou mesmo de algum de seus discípulos. Todavia, é difícil dar à imagem o nome de seu criador. São dados hipotéticos. Sem origem certa, a imagem de barro se reveste de um mistério kenótico. Uma imagem pobre, feita por um pobre, para os pobres. Quebrada, desprezada, foi lançada nas águas. No silêncio e na obscuridade, no esvaziamento da humilde imagem da Senhora da Conceição, Deus manifestará a sua glória.

\subsection{A pesca: primeiro sinal}

A primeira mensagem de Aparecida está relacionada ao dia em que a imagem foi encontrada. Era outubro de 1717. Os moradores da Vila de Guaratinguetá receberam ordens de apanhar o maior número possível de peixes porque o novo governador, Dom Pedro Miguel de Almeida Portugal e Vasconcelos, o Conde de Assumar, e sua comitiva iriam passar por aquelas terras. Segundo os poucos registros históricos ${ }^{12}$, três pescadores, Domingos Martins Garcia, João Alves e Filipe Pedroso, depois de navegarem uma certa distância sem apanhar peixe algum, ao lançarem as redes no chamado Porto de Itaguaçu, eis que colheram a imagem de Nossa Senhora da Conceição. Presa à rede, veio primeiro a imagem da Virgem sem a cabeça. Em seguida, ao lançar a rede novamente, veio a cabeça. Daquele momento em diante, se depararam com uma farta pescaria. Era o primeiro sinal: a pesca milagrosa.

O cenário do rio, da pesca e dos pescadores nos lembra claramente o chamado dos primeiros discípulos de Jesus. No avançar para águas mais profundas (Lc 5,4), eis que das profundezas surgiu

12 "O documento que associa o encontro da imagem de Nossa Senhora à visita do governador é o mais detalhado e mais valioso dos dois documentos que chegaram ao nosso tempo. Foi escrito em 1757, com base no relato de José Alves Vilella, pároco de Guaratinguetá, por um padre mestre em teologia e pouca paciência para detalhes. E é esse o texto que sustenta até hoje a grande parte da história da santinha" (ALVAREZ, Rodrigo. Aparecida: A biografia da santa que perdeu a cabeça, ficou negra, foi roubada, cobiçada pelos políticos e conquistou o Brasil. São Paulo: Globo, 2014. p. 104). 
um sinal de salvação: como outrora Moisés, a imagem "salva" das águas veio "salvar" um povo ${ }^{13}$. Pescadores simples do povo, com suas frágeis redes e seus barcos precários recebem um sinal de Deus. "A barca da Igreja não tem a força dos grandes transatlânticos que cruzam os oceanos. E, contudo, Deus quer se manifestar justamente através dos nossos meios, meios pobres, porque é sempre Ele que está agindo"14. Em nossa fragilidade, Deus nos convida à pesca. Pescadores de ontem e de hoje são chamados por Jesus para serem seus discípulos missionários, anunciadores de sua mensagem. " $\mathrm{O}$ resultado do trabalho pastoral não assenta na riqueza dos recursos, mas na criatividade do amor" ${ }^{15}$.

Os pecadores perceberam que a imagem abrigava um mistério. "Os pescadores não desprezam o mistério encontrado no rio, embora seja um mistério que aparece incompleto. Não jogam fora os pedaços do mistério. Esperam a plenitude" 16 . A imagem foi levada para a casa de um dos pescadores. "O povo simples tem sempre espaço para albergar o mistério"17. O mistério não é silenciado ou escondido, mas transmitido. Os pescadores convidam os vizinhos para se reunirem em oração diante da imagem. E eis que surge "uma graça, depois a outra; uma graça que abre para outra; uma graça que prepara outra. Gradualmente Deus vai desdobrando a humildade misteriosa de sua força" ${ }^{18}$.

$\mathrm{Na}$ vila de Guaratinguetá, passava o Rio Paraíba do Sul e a importante estrada que ligava Rio de Janeiro, São Paulo e Minas Gerais. Era um trajeto por onde passavam grandes caravanas, trazendo cargas valiosas extraídas das minas tão cobiçadas pelas metrópoles europeias. A primeira capelinha construída na beira dessa importante estrada foi a melhor forma de propagar a devoção à Senhora encontrada nas águas. Aparecida surgiu em um lugar de cruzamento, em uma encruzilhada do Brasil colonial, pois Deus aparece sempre nos cruzamentos de nossa história ${ }^{19}$.

13 GEBARA, Ivone; BINGEMER, Maria Clara L. Maria Mãe de Deus e mãe dos pobres: um ensaio a partir da mulher e da América Latina. Petrópolis: Vozes, 1987. p. 178.

14

15 Ibid., p. 50.

16 Ibid., p. 49.

17 Ibid., p. 49.

18 Ibid., p. 49.

19 Cf. Ibid., p. 50-51. 


\subsection{O sinal da imagem e seu significado antropológico}

Das profundezas, em meio ao lodo e à lama.

“A serpente, então, vomitou como um rio de água atrás da mulher, a fim de a submergir. A terra, porém, veio em socorro da mulher" (Ap 12,15-16a). A imagem de Aparecida veio das águas barrentas do Rio Paraíba. O próprio nome Paraíba, de origem Tupi, revela a condição real do rio: era um rio ruim ou imprestável. ${ }^{20}$ Eis que das profundezas desse rio imprestável surge uma pequenina imagem. A imagem da Virgem de Aparecida veio das profundezas, remetendo à situação em que se encontrava o povo oprimido pelo regime da escravidão negra e indígena e o povo pobre, sofrido, explorado pelos aliados à corte europeia e seus interesses mesquinhos. Em Aparecida, o grito do povo maltratado une-se ao sinal da imagem e à voz do salmista: "Das profundezas eu clamo a vós, Senhor, escutai a minha voz! Vossos ouvidos estejam bem atentos ao clamor da minha prece!" (S1 129,1-2). Em meio ao lodo e à lama, que indicam tanto o estado em que se encontrava a imagem quanto o povo vitimado pela colonização, o clamor intensifica-se: É o Senhor, que por meio de sua mãe, veio "retirar-nos da cova da morte, deste charco de lodo e de lama e colocar nossos pés sobre a rocha, devolvendo a firmeza a nossos passos" (S1 39,3).

Tirada das águas.

A água é elemento de rico significado teológico-sacramental. A água lembra libertação, vida, purificação, batismo. O sacramento do Batismo, "o banho da regeneração e da renovação no Espírito Santo" (Tt $3,5)$, significa e realiza o novo nascimento. Banhados em Cristo, somos purificados de nossos pecados e recebemos a liberdade de filhos e filhas. A imagem da Virgem tirada das águas alude à vida nova que recebemos em Cristo Jesus. A beleza de Deus refletida na Mãe da Conceição Aparecida, concebida sem pecado original, emerge da obscuridade de um rio ${ }^{21}$.

Uma imagem rejeitada e quebrada.

Era costume jogar imagens quebradas no rio, pois ficar com santo quebrado em casa poderia atrair coisa não muito boa. Quebrada, a imagem

20 Em Tupi, para significa rio, e aiba quer dizer ruim ou imprestável.

21 Cf. FRANCISCO, 2016, p. 48-49. 
de Nossa Senhora da Conceição foi lançada nas águas do Paraíba ${ }^{22}$. Tempos depois, pescadores colheram a imagem: primeiro veio o corpo e, em seguida, a cabeça. A imagem retratava a condição do Brasil colonial: um território dividido pela exploração dos recursos naturais, pela escravidão negra e indígena, pela desigualdade social, pelos interesses gananciosos de poderosos. Um Brasil dividido que refletia as circunstâncias nas quais se encontravam suas gentes. Um povo rejeitado, fragmentado, esquartejado pelas diversas formas de opressão já existentes, que teve sua dignidade roubada, ferida.

Mas Deus nunca esquece o seu povo. No gesto dos pescadores de unirem a cabeça ao corpo da imagem, Deus estava agindo. "Em Aparecida, desde o início, Deus dá uma mensagem de recomposição do que está fraturado, de compactação do que está dividido"23. Ao ser unido o corpo à cabeça, revela-se o desejo divino: Deus quer reconstituir o ser humano em sua integridade, quer libertá-lo de toda opressão. Ele quer unir uma nação, um povo. Deus coloca-se contrário às divisões e discórdias. A vontade de Deus é resgatar o ser humano, sua dignidade, principalmente, as vítimas das explorações.

\section{A Virgem da Conceição enegrecida.}

Não era difícil de encontrar uma imagem de Nossa Senhora da Conceição, pois, em 1646, ela se tornara padroeira de Portugal e de suas colônias. "Desde o século XIV, a doutrina sobre o mistério da Imaculada Conceição difundia-se por toda a península ibérica; promovida pelo magistério da Igreja e especialmente pelos Reis Católicos. Os missionários jesuítas aqui chegados foram os mensageiros da devoção à Mãe de Deus"24. A devoção à Virgem da Conceição foi trazida de Portugal para o Brasil: era uma virgem branca. Contudo, a imagem encontrada no rio estava escurecida. E, ao ser colocada para a veneração, com a fumaça das velas, sua cor foi ficando ainda mais intensa. A imagem assume a cor das gentes vitimadas pela escravidão. Maria faz-se negra para socorrer os seus filhos violentados pela miséria humana. Veio, em nome de seu filho, abolir o muro de separação: a inimizade, que separa, que mata (Ef

\footnotetext{
22 Esta seria a hipótese mais provável. Todavia, há quem defenda que a imagem possa ter sido arrastada até o rio por uma enchente, ou até mesmo ter caído nas águas por um descuido humano.

23 Ibid., p. 49.

24 GEBARA; BINGEMER, 1987, p. 179.
} 
2,14). "A Virgem de Aparecida passou a ser 'brasileira' como se mais uma nova identidade se acrescentasse a ela" 25 .

Com alguns estudos mais recentes,

peritos constataram que a imagem primitiva era originalmente policromada, tinha a pele do rosto e das mãos brancas, um manto de cor azul escuro e o forro vermelho granada. Estas eram as cores oficiais, conforme determinação de Dom João IV, de 25 de março de 1646, quando tornou a Santa Virgem, sob a invocação da Imaculada Conceição, Padroeira do Reino de Portugal e seus dominios. Ao longo dos anos, foi adicionado um sobremanto em forma triangular e uma coroa, o que permanece até os tempos atuais ${ }^{26}$.

Um dos primeiros milagres alcançados pela intercessão de Nossa Senhora Aparecida foi a libertação do escravo Zacarias. Conta-se que ao orar à porta do pequeno santuário que abrigava a Mãe Aparecida, o escravo acorrentado viu suas cadeias sendo rompidas. A Virgem que tinha se tornado negra veio quebrar os grilhões da escravidão. Ao desatar as correntes do escravo, Maria indicava o desejo de libertação daqueles que eram escravizados. Em um tempo de escravidão vigente no Brasil do século XVIII, "o povo lia os sinais de Maria como exigência de libertação" 27 . Podemos até imaginar que, ao rezar diante da imagem, a Princesa Isabel viu, na cor que a imagem trazia, o desejo divino de libertação, que a levou a cunhar a chamada lei do ventre livre, um primeiro passo e, depois, a própria abolição da escravatura.

O povo que sofria via refletida naquela imagem o seu próprio rosto. Esta identificação é registrada pelo padre Júlio Brustoloni em sua obra História de Nossa Senhora da conceição Aparecida: "Nos humildes e pobres pescadores e na imagem enegrecida e machucada o povo brasileiro viu-se identificado, como se tudo isto fosse cópia de sua própria vida e existência". ${ }^{28}$

Feita de terra brasileira.

"A origem do homem e da mulher, a origem da imagem da Senhora Aparecida e a origem da Basílica Nacional de Nossa Senhora de

\footnotetext{
25 GEBARA; BINGEMER, 1987, p. 181.

26 CAVALHEIRO, Elizangela. Os mantos da Mãe Aparecida: Conheça alguns fatos históricos sobre os mantos de Nossa Senhora Aparecida. Disponível em: <http://www.a12. com/santuario-nacional/noticias/detalhes/os-mantos-da-mae-aparecida-1>. Acesso em: 15 jan. 2017.

27 GEBARA; BINGEMER, 1987, p. 181.

28 CAVALHEIRO, 2017.
} 
Aparecida se entrelaçam: todas essas obras são feitas de barro"29. Feita de terracota, a imagem de Nossa Senhora Aparecida, provém de terras brasileiras, medindo tão somente 37 centímetros, sem a base de prata ${ }^{30}$. A imagem não foi feita com material nobre. Foi produzida, provavelmente, para ornamentar um pequeno altar ou oratório. "Uma imagem de barro frágil, escurecida pelas águas do rio, envelhecida pelo tempo. Deus entra sempre nas vestes da pequenez" ${ }^{\prime 1}$.

\section{A Princesa coroa a Rainha.}

O costume de colocar mantos, coroas e outros ornamentos é bastante antigo. Já temos referências históricas datadas em 1750 . O primeiro registro sobre o uso do manto cita o de cor carmesim. A imagem usou também vários cordões de ouro em volta do pescoço. Esses e outros adereços eram colocados na imagem, provavelmente, para disfarçar a quebra.

A princesa Isabel também viajou para rezar diante da Senhora Aparecida. A princesa e o Conde D'Eu não conseguiam ter filhos. Ao rezar à Senhora Aparecida, alcançaram a graça de terem não apenas um, mas três herdeiros. Em sinal de gratidão, a princesa Isabel ofertou à Virgem Aparecida uma coroa, que está atualmente junto à imagem original. "A coroa de ouro de 24 quilates, pesa 300 gramas e tem 24 diamantes maiores e 16 menores. Foi com ela que foi realizada a Coroação de Nossa Senhora Aparecida, em 1904. Dessa coroa, uma réplica está em exposição no Museu, junto com o manto utilizado na mesma celebração"32.

\section{Um atentado, uma dupla restauração ${ }^{33}$.}

Em 16 de maio de 1978, a imagem sofreu um grande atentado. Durante uma missa, na chamada Basílica Velha, um jovem quebrou o nicho onde estava a imagem, pegou a santa e, em seguida, assustado, deixou-a cair no chão. A pequenina imagem quebrou em mais de duzentos pedaços. A face direita ficou em migalhas. Em meio à poeira e aos minúsculos pedaços da imagem, foram recolhidas as peças de um quebra-cabeça.

29 APARECIDA. Fotos de Fabio Colombini e textos de Cláudio Pastro e Adélia Padro. Aparecida: Santuário, 2013. p. 16.

30 Durante a restauração da imagem, em 1978, pode-se constatar que ela é da primeira metade do século XVII, de artistas paulistas, tanto pela cor como pela qualidade do barro e pela sua feitura.

31 FRANCISCO, 2016, p. 48.

32 CAVALHEIRO, 2017.

33 Cf. CHARTUNI, Maria Helena. A História de dois restauros: Meu encontro com Nossa Senhora. Aparecida: Santuário, 2016. 
Acredita-se, inclusive, que alguns pedaços foram levados pelos próprios fiéis, já que partes da face direita jamais foram encontradas. A artista plástica Maria Helena Chartuni foi a responsável pela quase impossível tarefa de recuperar a imagem de Aparecida. No Museu de Arte de São Paulo (Masp) foram realizados os trabalhos de restauro ${ }^{34}$.

Dos mais de duzentos pedaços, apenas 165 estavam em condições de serem aproveitados. O restante foi misturado com cola e utilizado no interior da imagem e em outras superfícies ${ }^{35}$. Para unir as peças do quebra-cabeça, Maria Helena usou uma cola argentina, à base de epóxi. A cola agia como uma solda química. Por isso, antes de colar as partes, a restauradora unia cada pedaço com fita adesiva. A técnica não permitia imprecisões.

A face direita precisou ser reconstruída. Para tanto, a artista se baseou em duas réplicas da imagem e, também, na própria face esquerda da imagem original. Fez uma mistura usando massa Durepoxi e os minúsculos pedaços, quase em pó. Com esta massa que se formou e um pouco de cola, a face direita da santa foi recriada. Outros pedaços milimétricos que não puderam ser aproveitados foram misturados à própria cola e agregados à imagem em pontos mais frágeis e nas partes onde se fazia necessário. Nenhum pedacinho foi desperdiçado, mas agregado à imagem. A restauração uniu de vez a cabeça ao corpo, fazendo desaparecer a rachadura do pescoço, e incorporou um cabelo novo, comprido, que escorria pelas costas, substituindo a antiga massa feita de cimento.

Para esconder as marcas da restauração, a imagem precisou ser pintada. Após vários testes, Maria Helena escolheu a cor Terra Sienna queimada, uma cor marrom-escura que, segundo a artista, era a que mais se assemelhava à pátina que cobria a imagem quando chegou no Masp. Foram 33 dias ininterruptos de trabalho minucioso e complicado. Em seguida, a imagem foi levada em um caminhão do Corpo de Bombeiros e acompanhada por um grande cortejo de fiéis para Aparecida.

34 Durante os trabalhos de restauração pode-se perceber que, "em 1946, foi introduzido um pino de alumínio no pescoço da imagem, na tentativa de fixar a cabeça. O material empregado foi cola de origem animal e cimento, que serviu, também, para reconstruir a parte detrás dos cabelos e em alguns pontos da testa, também nos cabelos. Em 1950, novo conserto foi realizado, dessa vez, para fixar a cabeça e reforçar a pátina acanelada da imagem. Estas interferências foram realizadas pelos padres redentoristas Alfredo Morgano e Humberto Pieroni, respectivamente" (CHARTUNI, 2016, p. 21). A base de prata também foi introduzida posteriormente, em 1875, com a finalidade de dar estabilidade à imagem.

35 Ibid., p. 79. 
Com a sensação de dever cumprido e a satisfação de ter concluído o trabalho, a artista do Masp, durante o translado da imagem até Aparecida, testemunhou: "As pessoas a saudavam, rezando e se emocionando às lágrimas, na maior demonstração de fé espontânea que jamais havia visto em toda a minha vida. Naquele momento, a emoção tomou conta de mim e senti, pela primeira vez, que havia tocado em algo sagrado e inexplicável"36.

Maria Helena realizou a restauração sem cobrar nada. Fez tudo por amor. "Essa foi a minha maneira de entregar meu coração a ela, por meio de meu ofício, e assim continua até hoje" ${ }^{37}$, declarou a artista.

Pelas mãos da restauradora passaram obras de grandes mestres da arte. Contudo, a imagem de Aparecida era diferente. Ela não tinha assinatura, autoria; era anônima. Diante dessa constatação, Maria Helena se questiona:

Não seria este anonimato artístico providencial e necessário para ela cumprir a missão espiritual, destinada a proporcionar a tanta gente pobre, rica, culta ou inculta, a fé que transcende a qualquer explicação da lógica humana? Se o fenômeno Aparecida fosse apenas um produto de marketing católico, essa manifestação de fé que dura 300 anos teria continuado, ou teria desaparecido, após alguns anos, como em tantas manifestações "espirituais"? ${ }^{38}$

Concluído um restauro, a ligação entre a restauradora e a imagem encerrava-se. Todavia, com a imagem de Aparecida foi diferente. A artista confessa que mantém viva em sua memória cada detalhe do restauro e as suas diferentes sensações. O contato com o sagrado mudou a vida da restauradora, de uma indiferença cética para uma aceitação total. "Eu, sem saber, havia iniciado minha transformação, que me levaria a dizer, anos mais tarde, que Nossa Senhora começara, delicadamente, sutilmente, a restaurar minha vida, também despedaçada, enquanto eu juntava os fragmentos de sua imagem de terracota!" 39

O livro que Maria Helena escreveu foi intitulado A História de dois restauros. O primeiro diz respeito à reconstrução da imagem de

\footnotetext{
$36 \quad$ Ibid., p. 98.

$37 \quad$ Ibid., p. 103.

38 Ibid., p.107.

$39 \quad$ Ibid., p. 103.
} 
Nossa Senhora Aparecida e o segundo, conforme suas palavras, "foi o restauro da minha vida, que Nossa Senhora, paciente e amorosamente, fez comigo, libertando-me de um caminho tortuoso, por onde eu tinha enveredado" ${ }^{40}$. Em um dos painéis que se encontram dentro da Basílica Nova de Aparecida, Cláudio Pastro deixou registrada a memória desta grande mulher, a restauradora oficial da imagem de Nossa Senhora Aparecida.

Saqueada, alterada e refeita.

Durante os trabalhos de restauração, padre Isidro, reitor do Santuário, foi bastante inconveniente com seus palpites e sugestões. Seu maior descontentamento foi, principalmente, com relação à cor escolhida por Maria Helena para finalizar os trabalhos de restauro. Padre Isidro queria uma cor mais clara. Não satisfeito, depois da restauração, padre Isidro escondeu a imagem em seu quarto por vários dias, substituindo-a no nicho por uma réplica sem que ninguém notasse. Em seu quarto, alterou os traços do olho direito e pintou a imagem com tinta automotiva marrom. Em 16 de maio de 1979, exatamente um ano após o atentado, Maria Helena foi procurada pelos padres do Santuário para reparar os estragos que padre Isidro havia feito.

As mãos intactas.

Dentre os tantos pedaços em que se encontrava a imagem após o atentado, as mãos postas estavam lá, intactas. As mãos da Senhora permaneciam unidas em oração. Ao saber deste dado, João Paulo II, em 4 de julho de 1980, quando dedicou a nova Basílica Nacional, viu naquelas mãos "inquebrantáveis" uma mensagem de Deus: "O fato vale como símbolo: as mãos postas de Maria no meio das ruínas são um convite a seus filhos a darem espaço em suas vidas à oração, ao absoluto de Deus, sem o qual tudo o mais perde sentido, valor e eficácia. O verdadeiro filho de Maria é um cristão que reza" ${ }^{41}$.

\subsection{Os primeiros milagres: sinais dos tempos messiânicos}

A pesca abundante foi o primeiro de uma incontável gama de milagres. A sala de ex-votos do Santuário guarda o testemunho de tantos

\footnotetext{
40 Ibid., p. 111.

41 JOÃO PAULO II. Aparecida: Capital espiritual do Brasil. In: Os Papas e o Santuário de Aparecida. Coleção Theotókos. V. 15. Brasília: CNBB, 2016. p. 17.
} 
fiéis que alcançaram graças de Deus por intercessão de Nossa Senhora Aparecida. Os primeiros milagres, conservados devotamente pelo povo - a saber, o milagre das velas, a libertação do escravo Zacarias, a cura da menina cega e o milagre da ferradura -, são sinais da chegada dos tempos messiânicos.

Na sinagoga de Nazaré, em seu discurso inaugural, Jesus aplica a si mesmo o anúncio messiânico da profecia de Isaías: "O Espírito do Senhor está sobre mim, porque ele me consagrou com a unção para anunciar a Boa-Nova aos pobres; enviou-me para proclamar a libertação aos cativos e aos cegos a recuperação da vista; para libertar os oprimidos e para anunciar um ano da graça do Senhor" (Lc 4,18-19). Aquela passagem da Escritura cumpriu-se, novamente, nas terras de Aparecida. O Cristo, filho da Senhora Aparecida, trouxe a libertação aos escravos e oprimidos, a luz aos que jaziam nas trevas, a cura dos olhos aos cegos e uma boa notícia aos pobres e humildes.

\section{Aparecida aponta para Cristo: Maria à luz do Concílio Vaticano II}

O Concílio Vaticano II não preparou um documento específico sobre Maria, mas preferiu introduzir o tema marial no último capítulo da Constituição dogmática sobre a Igreja. Maria foi situada no mistério de Cristo e da Igreja, isto é, dentro da história da salvação e no contexto eclesiológico. Era a primeira vez que um Concílio oferecia uma síntese teológica sobre a Mãe de Jesus.

A Lumen Gentium ressaltou o caráter cristocêntrico do culto à Virgem Maria na Igreja: a veneração a Maria conduz à adoração do Senhor. O documento esclareceu, igualmente, a compreensão da intercessão de Maria. Reafirmando o dado bíblico da única mediação de Cristo, a Lumen Gentium declarou que a função maternal de Maria não ofusca ou diminui esta mediação única de Cristo; manifesta antes a sua eficácia. Trata-se, pois, de uma mediação derivada, dependente, participada e subordinada à mediação de Jesus. A mediação única do Cristo não exclui, mas suscita cooperações diversas, que participam dessa única fonte (LG, 60 e 62).

A Lumen Gentium exortou ainda a se abster tanto de qualquer falso exagero na devoção à Mãe de Deus, como também de demasiada pequenez de espírito, fomentando o seu culto litúrgico e estimando os legítimos exercícios de piedade (LG, 67). 
Paulo VI, na mesma perspectiva do Concílio, enfatizou, na $\mathrm{Ma}$ rialis Cultus, a importância de uma sóbria devoção mariana para "que os exercícios de piedade para com a Virgem Maria exprimam, de maneira clara, a característica trinitária e cristológica que lhes é intrínseca e essencial" (MC, 25).

Aprofundando o tema da mediação de Maria, João Paulo II, na Encíclica Redemptoris Mater, afirmou tratar-se de "uma mediação em Cristo" (RM, 38). A mediação maternal de Maria está intimamente ligada ao fato de Maria ter sido uma cooperadora generosa na obra da redenção (RM, 38). Maria "avançava na peregrinação da fé e, nessa sua peregrinação até aos pés da Cruz, foi-se realizando, ao mesmo tempo, com as suas ações e os seus sofrimentos, a sua cooperação materna e esponsal em toda a missão do Salvador" (RM, 39). Maria, assunta ao céu, continua o seu papel de intercessora (RM, 40). E nisso resume o sentido da mediação de Maria: uma "mediação que intercede" (RM, 40).

Confiantes na materna intercessão daquela que é proclamada Padroeira e Rainha do Brasil, devotos de todos os tempos e lugares, peregrinos e romeiros, invocam os auxílios de Nossa Senhora Aparecida. Em Aparecida, a Virgem Maria, como sempre fez, aponta para o Cristo. De fato, em Aparecida o centro é Jesus. No centro da Basílica está o altar, que é o próprio Cristo. O nicho onde se encontra a imagem da mãe Aparecida está localizado na nave sul do Santuário. Maria está lá, vestida de sol (cf. Ap 12,1), como que para nos indicar o filho. E Cristo, novamente, está a nos apresentar a sua mãe: "Esta é a tua mãe" (Jo 19,27). Pois, nas palavras do Papa Francisco, "em Aparecida, Deus ofereceu ao Brasil a sua própria Mãe"42.

\section{Referências}

ALVAREZ, Rodrigo. Aparecida: A biografia da santa que perdeu a cabeça, ficou negra, foi roubada, cobiçada pelos políticos e conquistou o Brasil. São Paulo: Globo, 2014.

CHARTUNI, Maria Helena. A História de dois restauros: Meu encontro com Nossa Senhora. Aparecida: Santuário, 2016.

CAVACA, Osmar. De quem é esta imagem? In: Iconografia de Aparecida: Teologia da Imagem. São Paulo: Paulus, 2016.

42 FRANCISCO, 2016, p. 48. 
CAVALHEIRO, Elizangela. Os mantos da Mãe Aparecida: Conheça alguns fatos históricos sobre os mantos de Nossa Senhora Aparecida. Disponível em: $<$ http://www.a12.com/santuario-nacional/noticias/detalhes/os-mantos-da-mae-aparecida-1>. Acesso em: 15 jan. 2017.

FRANCISCO. Aparecida: Chave de leitura para a missão da Igreja. In: Os Papas e o Santuário de Aparecida. Coleção Theotókos. V. 15. Brasília: CNBB, 2016.

GEBARA, Ivone; BINGEMER, Maria Clara L. Maria Mãe de Deus e mãe dos pobres: um ensaio a partir da mulher e da América Latina. Petrópolis: Vozes, 1987.

GUIMARÃES, Valdivino (Org.). Iconografia de Aparecida: Teologia da Imagem. São Paulo: Paulus, 2016.

JOÃO PAULO II. Aparecida: Capital espiritual do Brasil. In: Os Papas e o Santuário de Aparecida. Coleção Theotókos. V. 15. Brasília: CNBB, 2016.

MURAD, Afonso. Maria, toda de Deus e tão humana: Compêndio de mariologia. São Paulo: Paulinas; Aparecida: Santuário, 2012.

MURAD, Afonso. A devoção marial no Brasil contemporâneo: olhar panorâmico. Vida Pastoral, São Paulo, ano 56, n. 304, p. 3-14, jul/ago. 2015. 